\title{
Lutz's spontaneous sedimentation technique and the paleoparasitological analysis of sambaqui (shell mound) sediments
}

\author{
Morgana Camacho1, Thaíla Pessanha', Daniela Leles², Juliana MF Dutra', \\ Rosângela Silva ${ }^{3}$, Sheila Mendonça de Souza', Adauto Araujo ${ }^{1 /+}$ \\ 'Laboratório de Paleoparasitologia, Departamento de Endemias Samuel Pessoa, Escola Nacional de Saúde Pública Sergio Arouca \\ ${ }^{3}$ Laboratório de Helmintos Parasitos de Vertebrados, Instituto Oswaldo Cruz-Fiocruz, Rio de Janeiro, RJ, Brasil \\ ${ }^{2}$ Departamento de Microbiologia e Parasitologia, Instituto Biomédico, Universidade Federal Fluminense, Niterói, RJ, Brasil
}

Parasite findings in sambaquis (shell mounds) are scarce. Although the 121 shell mound samples were previously analysed in our laboratory, we only recently obtained the first positive results. In the sambaqui of Guapi, Rio de Janeiro, Brazil, paleoparasitological analysis was performed on sediment samples collected from various archaeological layers, including the superficial layer as a control. Eggs of Acanthocephala, Ascaridoidea and Heterakoidea were found in the archaeological layers. We applied various techniques and concluded that Lutz's spontaneous sedimentation technique is effective for concentrating parasite eggs in sambaqui soil for microscopic analysis.

Key words: coprolites - paleoparasitology - sambaqui - archaeological sediments - helminthiasis - ancient diseases

The primary aim of paleoparasitology research is to establish the foundations of the origin and evolution of infectious diseases. Therefore, paleoparasitological studies are dedicated to the recovery and interpretation of parasite remains found in archaeological and paleontological material. The data obtained may be analysed using a paleoepidemiological approach (Ferreira 2011). Parasites may be preserved in coprolites, mummified bodies, latrine sediments and any other type of material found at archaeological and paleontological sites.

Shell mounds, or sambaquis (as they are known in Brazil), are archaeological sites intentionally built by prehistoric hunter/fisher/gatherer groups that inhabited the Brazilian coast. These sites are generally composed of several superposed layers of various types of materials, including hearth charcoals, ashes, clay, burnt/ broken shells of different types, burnt animal bones and other organic remains. Shells represent the major component, but animal bones (especially fish bones) are also found (Gaspar 2004). These sites were built adjacent to fresh water sources, such as rivers and lakes, close to the seashore. As they are mainly located on the coast, these sites are exposed to tides, rainfall and flooding, which are characteristic of tropical latitudes, thus favouring both microorganism proliferation and poor preservation of organic material, including faecal material (Gaspar 2004, Leles 2010).

Despite the archaeological importance of these sites, records of parasite eggs found in sambaquis have only

Financial support: PRONEX/FAPERJ, CNPq

+Corresponding author: adauto@ensp.fiocruz.br

Received 7 April 2012

Accepted 20 July 2012 been recently reported. The first positive result in Brazilian sambaqui soil samples was obtained in our laboratory by Teixeira-Santos (2010), who found an egg of Trichuris sp. in the sediment collected from the pelvic girdle of one skeleton of the sambaqui of Cubatão I, state of Santa Catarina, southern Brazil. This finding was supported by Leles (2010), who recovered Ascaris lumbricoides and Trichuris trichiura DNA in the pelvic girdle of another skeleton at the same archaeological site.

Since we began our paleoparasitological research in the 1980s, our laboratory has received soil samples from sambaquis for analysis. We used the recommended technique to recover parasites from soil samples (Caldwell \& Caldwell 1928). Initial analyses were negative for parasite remains. A few years later, we applied a technique recommended by Jones (1982) on other sambaqui samples, which also yielded negative results. Fugassa et al. (2006) have modified the technique described by Jones (1982), which increased the sediment quantity and was successfully applied in parasite research involving archaeological soil. This technique also yielded negative results when applied to sambaqui samples.

Our laboratory team has examined 121 sambaqui samples, but each sample tested negative for parasites. As the recommended techniques for parasitological analysis of soil (Caldwell \& Caldwell 1928, Jones 1982) failed to recover parasite eggs, spontaneous sedimentation (Lutz 1919) was then applied in combination with the technique established by Fugassa et al. (2006). Since the first analysis of ancient material in our laboratory, the spontaneous sedimentation technique (Lutz 1919) was applied for parasite research in coprolites, but never for soil analyses.

We recommend the spontaneous sedimentation technique described by Lutz (1919) to recover parasite vestiges in sediment samples from sambaqui archaeological sites. Herein, we report the first results and discuss the techniques. 


\section{MATERIALS AND METHODS}

The samples analysed in this study originated from the sambaqui of Guapi located in the municipality of Guapimirim, Rio de Janeiro, close to the Guapi River (Pinto 2009). The coordinates of this site, which is still under study, are $22^{\circ} 38^{\prime} 9.90^{\prime \prime} \mathrm{S} 42^{\circ} 56^{\prime} 10.74^{\prime \prime} \mathrm{W}$. No radiocarbon dates are available.

A multidisciplinary team from the Nacional Museum of Federal University of Rio de Janeiro collected a total of 14 sediment samples isolated from different archaeological layers and the surface layer served as a control. The samples were sent to the laboratory of paleoparasitology for analyses.

After applying the Fugassa et al. (2006) flotation technique, which yielded negative results for parasites, we applied the spontaneous sedimentation technique (Lutz 1919). We used $5 \mathrm{~g}$, which is a little more than the amount used for fresh faeces (2-4 g).

The samples were rehydrated in $0.5 \%$ trisodium phosphate aqueous solution $\left(\mathrm{Na}_{3} \mathrm{PO}_{4}\right)$ for $72 \mathrm{~h}$ (Callen \& Cameron 1960) to recover the desiccated organic remains. Next, we applied the spontaneous sedimentation (Lutz 1919) technique to concentrate the parasite eggs, larvae and cysts. For the sambaqui soil analyses, we separated 5 $\mathrm{g}$ of the sediment and proceeded with the standard recommendations. The rehydrated sediment was disaggregated with a glass rod, strained through triple doubled gauze on a glass funnel into conical glass jars and left to sediment for $24 \mathrm{~h}$ (Fig. 1). Drops of the sediment were taken from the bottom with Pasteur pipettes and 20 slides of each sample were prepared and examined using a bright-field microscope. Parasite eggs and other microscopic residues were measured with an ocular micrometre. Digital photographs were taken at $400 \mathrm{X}$.

\section{RESULTS}

The samples from the surface layer were negative for parasite eggs, larvae and cysts. Two of the eight samples isolated from the archaeological layers were positive for Heterakoidea, Acanthocephala and Ascaridoidea eggs. The measurements of the eggs and the possible hosts of the parasites are shown in Table I.

Eggs of the superfamily Heterakoidea are either ovoid or round-shaped, with a double smooth thick eggshell and amorphous content (Fig. 2). Ascaridoidea eggs are yellowish and oval-shaped, with the wrinkled mammillated eggshell characteristics of the family Ascaridae (Rey 2008) (Fig. 3).

Acanthocephala eggs are characteristically elliptical with only the inner eggshell preserved. The outer eggshell is poorly preserved with an amorphous contour (Fig. 4A, B).

The samples were also analysed for coprophagic and nematophagous fungi and mites. The samples that tested positive for parasite eggs did not contain spores that were morphologically similar to either coprophagic or nematophagous fungi (van Geel et al. 2003). In a sample that was negative for parasites, a significant quantity of coprophagic and nematophagous fungal spores were found (Table II). Mites were not found in the samples.

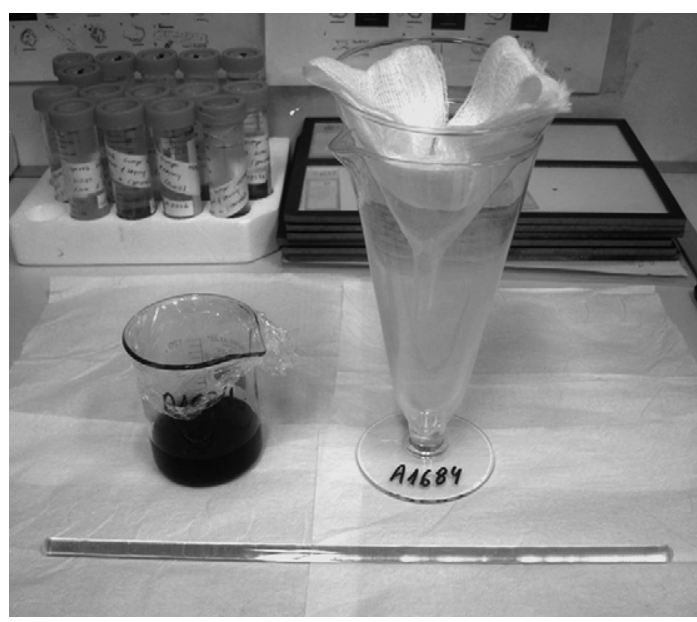

Fig. 1: conical glass jar used for Lutz's sedimentation technique.

\section{DISCUSSION}

Despite the archaeological significance of the Brazilian sambaquis and other similar archaeological sites, there are few records of parasite eggs found in shell mounds. Bathurst (2005) has identified Diphyllobothrium spp, Ascaris lumbricoides, Nanophyetus salmincola and tapeworm eggs in a Canadian midden using sample centrifugation and by analysing the top layer of the centrifuged sediment. Bouchet et al. (1999) have identified Diphyllobothrium spp and hookworm eggs in midden material isolated in Alaska, United States of America, using $0.5 \%$ glycerinated water suspensions, sedimentation and flotation techniques.

The technique described by Caldwell and Caldwell (1928) was first used in our laboratory to identify parasites in the first half of the sediment samples, which consists primarily of sambaqui sediments. This approach failed to yield positive results. Next, the flotation technique was used, especially after the successful application in ancient sediments that were exposed to thermal and chemical stress, high percolation and significant amounts of sand, which occur in the Patagonian region (Fugassa et al. 2006). These conditions are similar to those found in sambaquis. However, despite the positive results obtained in Patagonian soil, the sediment analysis results from the sambaquis were negative for parasites.

The spontaneous sedimentation technique (Lutz 1919) was originally developed for fresh faeces analysis aimed to diagnose Schistosoma mansoni eggs in faeces. The technique is recommended to detect most protozoan and helminth intestinal parasites and it is considered to be highly sensitive, easily applicable and inexpensive (Ferreira 1966). In 1934, Hoffman, Pons and Janer described the same technique for $S$. mansoni egg research (Hoffman et al. 1934).

Jiménez et al. (2012) tested both the spontaneous sedimentation and flotation techniques in coprolites isolated in Mexico. The results were better with the former technique, as it allowed for the retrieval and identifica- 
TABLE I

Measurements of parasite eggs found in sambaqui of Guapi archaeological sediments, Rio de Janeiro, Brazil

\begin{tabular}{lccc}
\hline Parasite eggs & Host & $\begin{array}{c}\text { Length } \\
(\mu \mathrm{m})\end{array}$ & $\begin{array}{c}\text { Width } \\
(\mu \mathrm{m})\end{array}$ \\
\hline Heterakoidea (Fig. 2) & $\begin{array}{c}\text { Fowl, rodents, } \\
\text { reptiles and marsupials }\end{array}$ & 92.8 & 85.6 \\
Ascaridoidea (Fig. 3) & $\begin{array}{c}\text { Humans, chimpanzee, } \\
\text { gorilla, gibbon, rhesus monkey, } \\
\text { cattle, sheep, goat, swine, horse, } \\
\text { dog, cat and poultry } \\
\text { Mammals, fish, amphibians } \\
\text { Acanthocephala (Fig. 4A) }\end{array}$ & 79.3 & 66.2 \\
Acanthocephala (Fig. 4B) & and birds & 113.6 & 53.1 \\
\hline
\end{tabular}

tion of more species of parasites. Furthermore, the spontaneous sedimentation technique (Lutz 1919) allows for the concentration of a great number of parasite eggs in the conical bottom of the vessel, thereby enabling the recovery of small quantities of eggs.

Lutz's spontaneous sedimentation technique has also been applied in coprolites for paleoparasitological analysis, with the first studies conducted in our laboratory. The content retained in gauze should be analysed for food remains in a stereomicroscope. We recommend preparing 20 slides for each coprolite sample to be examined by light microscopy. The remaining sediment should be stored at a low temperature in a refrigerator and other samples should be preserved in $10 \%$ formaldehyde acetic solution (Raillet \& Henry solution). Lutz's spontaneous sedimentation technique was selected as the best technique for archaeological samples, as this method allows the preservation of all material used during the various steps, and no material is lost, which is the primary goal when dealing with archaeological material.

After obtaining negative results with the technique developed by Fugassa et al. (2006), the spontaneous sedimentation (Lutz 1919) technique was successfully applied by Teixeira-Santos (2010) on sambaqui sediment samples, which yielded positive results for parasite eggs (T. trichiura). Teixeira-Santos (2010) suggested the use of this technique when the archaeological site is characterised by taphonomic factors that hamper paleoparasitological diagnoses, as is the case in sambaqui soil.

Taphonomic factors probably represent the major influence hampering the identification of parasite eggs in sambaquis (Leles et al. 2010). Coprophagic and nematophagous fungi, mites and other invertebrates are commonly found in sambaqui soil, which contributes to the poor preservation of organic material from the moment of its deposition into the soil until the time of storage and transportation to the laboratory (Sagara et al. 2008). The absence of parasite eggs in some samples can possibly be explained by the significant quantity of coprophagic and nematophagous fungi found in sambaqui soil (Leles et al. 2010). However, to understand the basic principles of the degeneration of parasite eggs by this type of fungi, further investigation is required.

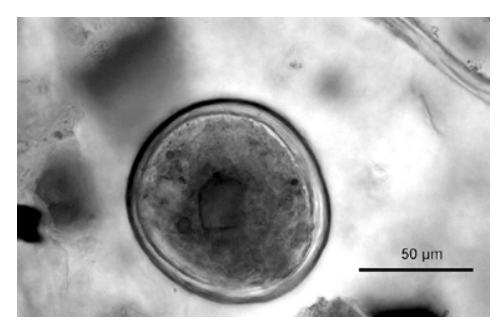

Fig. 2: egg of the superfamily Heterakoidea found in sambaqui of Guapi archaeological sediments, Rio de Janeiro, Brazil.

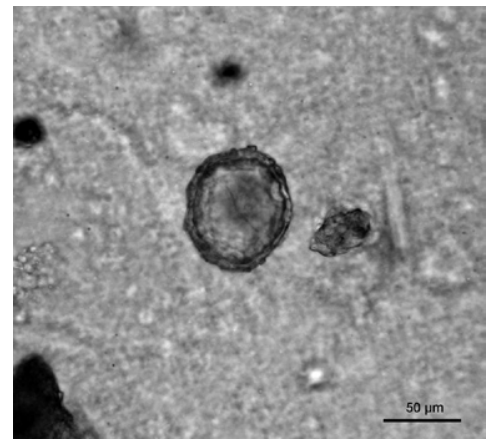

Fig. 3: egg of superfamily Ascaridoidea found in sambaqui of Guapi archaeological sediments, Rio de Janeiro, Brazil.

A

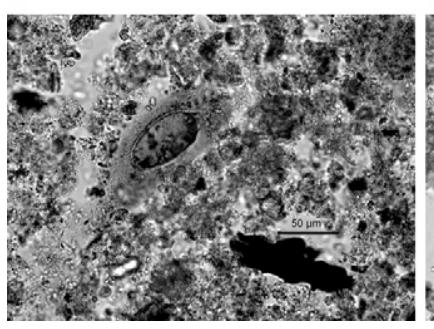

B

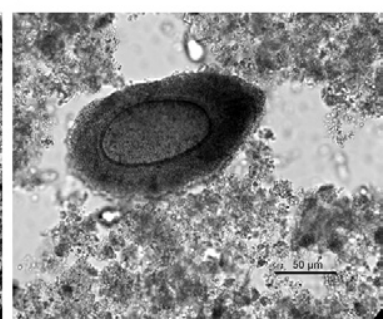

Fig. 4A, B: eggs of phylum Acanthocephala found in sambaqui of Guapi archaeological sediments, Rio de Janeiro, Brazil. 


\section{TABLE II}

Relation between parasite positivity and fungi spores found in each sample of sambaqui of Guapi archaeological sediments, Rio de Janeiro, Brazil

\begin{tabular}{|c|c|c|c|}
\hline Samples & $\begin{array}{l}\text { Parasites } \\
\text { eggs } \\
\text { (n) }\end{array}$ & $\begin{array}{l}\text { Fungi spore } \\
\text { not considered } \\
\text { coprophagic } \\
\text { (n) }\end{array}$ & $\begin{array}{l}\text { Fungi spores } \\
\text { morphologically similar } \\
\text { to coprophilous fungi }{ }^{a} \\
\text { (n) }\end{array}$ \\
\hline 1 & - & 20 & 1 \\
\hline 2 & - & 23 & 1 \\
\hline 3 & - & 20 & 2 \\
\hline 4 & - & 8 & - \\
\hline 5 & - & 19 & 1 \\
\hline 6 & - & 9 & - \\
\hline 7 & - & - & 133 \\
\hline 8 & $2^{b}$ & - & - \\
\hline 9 & - & 3 & - \\
\hline 10 & $3^{c}$ & 1 & - \\
\hline 11 & - & 1 & - \\
\hline 12 & - & 1 & - \\
\hline 13 & - & - & - \\
\hline 14 & - & 1 & - \\
\hline
\end{tabular}

$a$ : Van Geel et al. (2003); $b$ : one egg of Heterakoidea; $c$ : two eggs of Acanthocephala and one egg of Ascaridoidea.

The parasite eggs found in the sambaqui of Guapi have prompted interesting speculations. Although the Acanthocephala and Heterakoidea species are not commonly found in humans, they may occasionally cause true infections in the human host. Interestingly, Acanthocephala eggs have been found at archaeological sites associated with humans (Fry \& Hall 1969, Moore et al. 1969, Fry 1970, Schmidt 1971, Ferreira et al. 1989, Fugassa et al. 2011). Parasites of the Acanthocephala phylum are primarily transmitted by the consumption of infected arthropods, which act as intermediate hosts (Moore et al. 1969, Vicente et al. 1997). Birds, fish and mammals, including humans, represent the definitive vertebrate hosts.

Ascaridoidea eggs are commonly found in ancient samples. Since the earliest paleoparasitological studies, Ascaris eggs have been found in archaeological samples, especially in Europe (Taylor 1955, Pike 1967, Greig 1981, Jones et al. 1988, Bouchet 1991, 1993, 1995, Bouchet \& Paicheler 1995, Bouchet et al. 1996, 1998, Rousset et al. 1996, Fernandes et al. 2005, Le Bailly et al. 2005). At archaeological sites of South America, Ascaris sp. eggs are rarely found (Ferreira et al. 1980, Patrucco et al. 1983, Gonçalves et al. 2003, Fugassa \& Guichón 2006, Fugassa et al. 2008), which is apparently because the eggs are poorly preserved (Leles et al. 2010). Leles (2010) has suggested that coprophagic fungi may interfere with egg and, consequently, DNA preservation. A large number of mammals, including humans, are infected by species of these parasites. In the present case, based on the morphological parameters of only one egg, it is impossible to identify the species. Therefore, we conclude that the results suggest an ascarid-like egg.

Parasites of the Heterakoidea superfamily display a cosmopolitan distribution. Species of this superfamily have been found infecting various orders of mammals, especially rodents (Jiménez \& Gardner 2004). There is only a record of Heterakoidea eggs in ancient samples (Bouchet 1991). Therefore, the present finding is relevant because it not only depicts parasite eggs found in a difficult preservation environment, but it also suggests an unusual parasite associated with human remains.

Soil contamination by faecal material in modern times cannot be ignored, especially considering parasite egg dispersion by percolation. Soil disturbance, tide movement, floods and heavy rainfall can easily disperse eggs. Therefore, careful excavations to establish archaeological contexts are needed. Although the sambaqui of Guapi is still under study, the archaeological layers are defined. The results presented here represent the first findings of parasite eggs that are well preserved in the sambaquis and demonstrate that the spontaneous sedimentation technique (Lutz 1919) is recommended for concentrating parasite eggs.

Although the techniques described by Caldwell and Caldwell (1928), Jones (1982) and Fugassa et al. (2006) are indicated for parasitological analyses of various types of sediment, the spontaneous sedimentation technique (Lutz 1919) yielded better results than the others in the case of sambaqui sediments. The techniques that were described by Jones (1982) and modified by Fugassa et al. (2006) should be used in archaeological soil sediments. However, we recommend the spontaneous sedimentation (Lutz 1919) technique for sambaqui samples; this technique was successfully applied in this report for paleoparasitological research.

The finding of Acanthocephala, Ascaroidea and Heterakoidea eggs represents the first report of the presence of these parasites in sambaqui sediments. Although the archaeological context is still under study, the findings show that parasite eggs could be preserved in sambaqui soil.

\section{ACKNOWLEDGEMENTS}

To the archaeological team of Nacional Museum, UFRJ, for collecting the samples.

\section{REFERENCES}

Bathurst RR 2005. Archaeological evidence of intestinal parasites from coastal shell middens. J Archaeol Sci 32: 115-123.

Bouchet F 1991. Étude parasitologique des chantiers archéologiques de Beauvais (Oise). Rev Archeol Picardie 3/4: 293-294.

Bouchet F 1993. Apport de la parasitologie sur les chantiers archéologiques. L'exemple de la ville de Paris. Mém Groupement Archeol de Seine-et-Marne 1: 55-61.

Bouchet F 1995. Recovery of helminth eggs from archaeological excavations of the Grand Louvre (Paris, France). J Parasitol 81: 785-787.

Bouchet F, Baffier D, Girard M, Morel PH, Paicheler JC, David F 1996. Paleoparasitology in a Pleistocene context: initial observations in the Grande Grotte at Arcy-sur-Cure (Department of the Yonne, France). CR Acad Sci Ser III 319: 147-151.

Bouchet F, Bentrad S, Paicheler JC 1998. Enquête épidémiologique sur les helminthiases à la cour de Louis XIV. Mèdecine/Sciences 14: 463-466. 
Bouchet F, Lefèvre C, West D, Corbett D 1999. First paleoparasitological analysis of a midden in the Aleutian Island (Alaska): results and limits. $J$ Parasitol 85: 369-372.

Bouchet F, Paicheler JC 1995. Paleoparasitology: pressumption of bilharziose on an archaeological site from XV century of Montbeliard (Doubs, France). CR Acad Sci Ser III 318: 811-814.

Caldwell FC, Caldwell EL 1928. Preliminary report on observations on the development of ova of pig and human Ascaris under natural conditions and studies of factors influencing development. J Parasitol 14: 254-260.

Callen EO, Cameron TWM 1960. A prehistoric diet as revealed in coprolites. New Sci 8: 35-40.

Fernandes A, Ferreira LF, Gonçalves MLC, Bouchet F, Klein CH, Iguchi T, Sianto L, Araújo A 2005. Intestinal parasite analysis in organic sediments collected from a 16th-century Belgian archeological site. Cad Saude Publica 21: 329-332.

Ferreira LF 1966. Exame parasitológico de fezes. Estudo comparativo das principais técnicas. Hospital (Rio J) 70: 347-368.

Ferreira LF 2011. Introdução à paleoparasitologia. In L Ferreira, KJ Reinhard, A Araújo, Fundamentos da paleoparasitologia, Fiocruz, Rio de Janeiro, p. 27-41.

Ferreira LF, Araújo A, Confalonieri U 1980. The finding of eggs and larvae of parasitic helminths in archaeological material from Unai, Minas Gerais, Brazil. Trans R Soc Trop Med Hyg 74: 798-800.

Ferreira LF, Araújo A, Confalonieri U, Chame M 1989. Acanthocefalan eggs in animal coprolites from archaeological sites from Brazil. Mem Inst Oswaldo Cruz 84: 201-203.

Fry GF 1970. Preliminary analysis of Hogup Cave coprolites, Appendix III. In CM Aikens, Hogup Cave, The University of Utah Anthropological Papers 93, University of Utah Press, Salt Lake City, p. 247-250.

Fry GF, Hall HJ 1969. Parasitological examination of prehistoric human coprolites from Utah. Proc Utah Acad Sci Art Letters 46: 102-105.

Fugassa MH, Araújo A, Guichón RA 2006. Quantitative paleoparasitology applied to archaeological sediments. Mem Inst Oswaldo Cruz 101 (Suppl. II): 29-33.

Fugassa MH, Guichón RA 2006. Nuevos aportes a la paleoparasitología del sitio arqueológico "Nombre de Jesús" (s.XVI), Cabo Virgenes, Argentina. Rev Arg Antropol Biol 8: 73-83.

Fugassa MH, Reinhard KJ, Johnson KL, Gardner SL, Vieira M, Araújo A 2011. Parasitism of prehistoric humans and companion animals from Antelope Cave, Mojave County, Northwest Arizona. J Parasitol 97: 862-867.

Fugassa MH, Sardella NH, Guichón RA, Denegri GM, Araújo A 2008. Paleoparasitological analysis applied to museum-curated sacra from meridional Patagonian collections. J Archaeol Sci 35: 1408-1411.

Gaspar MD 2004. Sambaqui: arqueologia do litoral brasileiro, 2nd ed., Jorge Zahar, Rio de Janeiro, 89 pp.

Gonçalves MLC, Araújo A, Ferreira LF 2003. Human intestinal parasites in the past: new findings and a review. Mem Inst Oswaldo Cruz 98: 103-118.

Greig J 1981. The investigation of a medieval Barrel-latrine from Worcester. J Archaeol Sci 8: 265-282.

Hoffman WA, Pons JA, Janer JL 1934. The sedimentation-concentration method in schistosomiasis mansoni. Puerto Rico J Public Health Trop Med 9: 283-291.

Jiménez FA, Gardner SL 2004. The concerted evolution of mammals and nematodes (Heterakoidea: Aspidoderidae) in South America.
Joint meeting of 49th Annual Meeting of the American Association of Veterinary Parasitologists and 79th Meeting of The American Society of Parasitologists, Philadelphia, July 24-28, p. 71.

Jiménez FA, Gardner SL, Araújo A, Fugassa M, Brooks RH, Racz E, Reinhard KJ 2012. Zoonotic and human parasites of inhabitants of Cueva de los Muertos Chiquitos, Rio Zape Valley, Durango, Mexico. J Parasitol 98: 304-309.

Jones AKG 1982. Recent finds of intestinal parasite ova at York, England. Proc Paleopathol As, 4th European Meeting, Middelburg, p. 7.

Jones AKG, Hutchinson AR, Nicholson C 1988. The worms of Roman horses and other finds of intestinal parasite eggs from unpromising deposits. Antiquity 62: 275-276.

Le Bailly M, Leuzinger U, Schlichtherle H, Bouchet F 2005. Diphyllobothrium: neolithic parasite? J Parasitol 91: 957-959.

Leles D 2010. Paleogenética e paleoepidemiologia de Ascaris sp (Linnaeus, 1758) e Trichuris sp (Roederer, 1761), DSc Dissertation, Escola Nacional de Saúde Pública/Fiocruz, Rio de Janeiro, 162 pp.

Leles D, Reinhard KJ, Fugassa M, Ferreira LF, Iñiguez AM, Araújo A 2010. A parasitological paradox: why is ascaris infection so rare in the prehistoric Americas? J Archaeol Sci 37: 1510-1520.

Lutz A 1919. O Schistosomum mansoni e a schistosomatose, segundo observações feitas no Brasil. Mem Inst Oswaldo Cruz 11: 121-155.

Moore JG, Fry GF, Englert E 1969. Thomy-headed worm infection in North American prehistoric man. Science 163: 1324-1325.

Patrucco R, Tello R, Bonavia D 1983. Parasitological studies of coprolites of pre-hispanic Peruvian populations. Curr Anthropol 24: 393-394.

Pike AW 1967. The recovery of parasite eggs from ancient cesspit and latrine deposits: an approach to the study of early parasite infections. In D Brothwell, AT Sandison, Diseases in antiquity, CC Thomas Springfield, London, p. 184-188.

Pinto DC 2009. Concha sobre concha: construindo sambaquis e a paisagem no Recôncavo da Baía de Guanabara, MSc Thesis, Museu Nacional da Universidade Federal do Rio de Janeiro, Rio de Janeiro, $161 \mathrm{pp}$.

Rey L 2008. Ascaris lumbricoides e Ascaríase. In L Rey, Parasitologia, 4th ed., Guanabara Koogan, Rio de Janeiro, p. 585-597.

Rousset JJ, Heron C, Metrot P 1996. Helminthoses humaines chez les Gaulois. Hist Sci Med 30: 41-46.

Sagara N, Yamanaka T, Tibbett M 2008. Soil fungi associated with graves and latrines: toward a forensic mycology. In M Tibbett, DO Carter, Soil analysis in forensic taphonomy: chemical and biological effects of buried human remains, CRC Press, New York, p. 67-107.

Schmidt GD 1971. Acanthocephalan infections of man, with two new records. J Parasitol 57: 582-584.

Taylor EL 1955. Parasitic helminths in mediaeval remains. Vet Rec 67: $218-228$.

Teixeira-Santos I 2010. Residuos alimentares, infecções parasitárias e evidência do uso de plantas medicinais em grupos pré-históricos das Américas, MSc Thesis, Escola Nacional de Saúde Pública, Fiocruz, Rio de Janeiro, 103 pp.

van Geel B, Buurman J, Brinkkemper O, Schelvis J, Aptroot A, van Reenen G, Hakbijl T 2003. Environmental reconstruction of a Roman Period settlement site in Uitgeest (The Netherlands), with special reference to coprophilous fungi. J Archaeol Sci 30: 873-883.

Vicente JJ, Rodrigues HO, Gomes DC, Pinto RM 1997. Nematóides do Brasil. Parte V: Nematóides de Mamíferos. Rev Bras Zool 14: 452. 